\title{
Constructing Readers and Reading Communities: Marguerite de Navarre's Heptaméron 32 in England ${ }^{1}$ \\ MELISSA \\ WALTER
}

Résumé : En général, les collections de nouvelles françaises et italiennes de la Renaissance montrent une pratique de lecture active et réfléchie à laquelle les femmes et les hommes participent. Heptaméron 32 de Marguerite de Navarre donne au lecteur le rôle d'un témoin responsable à travers le personnage de Bernage. Dans leurs versions anglaises de cette nouvelle, William Painter et George Whetstone transforment le cadre et modifient le role du lecteur, tout en s'appropriant l'idée que lire et interpréter sont des processus sociaux qui peuvent refaçonner l'individu.

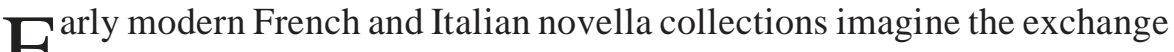
- 0 fictions as a social and ethical experience, valuable both for recreation and as an opportunity to discuss conduct, beliefs, and norms. The communities of readers they represent were not unproblematic, however, for their collective discussions often convey disagreement about moral choice, character, or the meaning of actions. This kind of debate and even bitter disagreement, often represented along gender lines, gave an unusual openendedness to the form of the novella collection. It also provided a concept of ethical division that helped to shape a new sense of individual identity, an identity that was socially expressed and defined, yet recognized individual interpretations as signs of interiority. In translating novellas into English, Elizabethan writers borrowed this model, so that the novella became one of the forms through which reading was imagined as social in early modern England. Crossing back and forth over the line between history and fiction, novella collections invite questions about the role of fiction in shaping the sense an individual could make of his or her relationships to 
others or choices in social situations. In the continental models, both men and women are active discussants and story-tellers.

While novellas often take narration or wit as their topic as well as their mode of proceeding, Heptaméron 32, the focus of this essay, stands out for its unusually complex portrayal of reading, retelling, and action in response to fictional forms. Heptaméron 32 places the reader in a position of responsible witness when Bernage, Seigneur de Sivray, a figure for the reader within the tale, becomes the mediator between a disturbed private household and the realm of history and politics. In translating and adapting this tale, two English writers, William Painter and George Whetstone, reframe the tale and shape the role of the reader. While Painter in his Palace of Pleasure (vol. 1 pub. in 1566 and 1569; vol. 2 in 1567; both vols. again in 1575) gives the reader very little direct instruction for interpreting the tale, Whetstone in his Heptameron of Civill Discourses (1582) places the tale within a discussion of the dangers of unequal marriage, directing the reader to desire a marriage partner of equal status and wealth. But in spite of the different degrees to which they leave their reader free to interpret the stories as he or she sees fit, both adapt the notion that reading and interpreting is a social process that can reshape the self and in which both men and women can be actors.

In most novella collections, stories are nested within stories (notably the frame tale, the overarching narrative within which individual stories are told), and listeners and readers become speakers and writers. The Heptaméron of Marguerite de Navarre in particular stands out for its extended discussions following each tale, discussions in which the diversity of the discussants' views invites the reader to continue to engage with the ethical, spiritual, social and aesthetic issues raised. While the frame tale can be read as a way of bracketing off a ludic story-telling space, it can also be read as a step in a regress of stories framed by stories that need not stop at the boundaries of the book. ${ }^{2}$ Though narrator, character, and reader are theoretically distinct roles - characters are not necessarily narrators, and a reader cannot normally intervene in the progress of a tale - these roles are flexible in the Heptaméron, and in novella collections generally. ${ }^{3}$ The nesting of story within story and the movement of the discussants (devisants) between the roles of narrator and listener (which is analogous to a movement between author and reader) invite consideration of how an actual reader might respond and react to a fictional tale, perhaps by producing more narrative or by taking action in the realm of his or her lived experience. ${ }^{4}$ With its declared goal "de n'escripre nulle nouvelle qui ne soit veritable histoire" 5 prefacing stories with known fictional sources (or that are strongly marked by genres such as romance and fabliau), as well as stories based on contemporary gossip, the Heptaméron emphasizes a mutual permeability of fiction and history. ${ }^{6}$ 
Particularly because the discussions following the tales address the ethical status of the actions within them (including decisions about whether to tell or not tell stories), the stories come to point outward from their frame toward the ethical position of the reader, who is both a potential story teller and a historical actor. The devisants of the Heptaméron reveal how the frame tale can function as a model society for the reader, both a way of communicating the substance of contentious issues and a method for negotiating them. This model society also provides a model for reading: fictions are understood always to point outwards and to be incomplete if the readers have not drawn the connections between their own ethical dilemmas (what we might call real or non-fictional ethical dilemmas) and those that are represented within the story. While this model of reading has analogies to the demands made on the reader by Medieval and Renaissance allegory, the novella (and especially the novella collection) is the first genre to build this reading practice into a narrative claiming to be anchored in history and social reality (even if novellas and their frame tales are not entirely bound by the norms of verisimilitude).

In Heptaméron 32, Bernage, Seigneur de Sivray, becomes a figure for the reader by being an "inscribed listener" within the tale itself; following the story-within-story structure of the Heptaméron, the husband in Heptaméron 32 narrates his story to Bernage, Bernage narrates his own version of the story to Charles VIII and to Oisille (the devout older lady who directs the activities of the group), Oisille narrates her version to the listeners, and Marguerite de Navarre writes the tale for the reader of the Heptaméron. ${ }^{7}$ In each case, the story produces a response (including action, discussion of ideas and principles, and another narration of the story to a new audience), but the response of the reader of the Heptaméron remains to be supplied. Among the many stories in the Heptaméron that are about gendered violence, the problematics of human desire, and telling and listening to stories, Heptaméron 32 is particularly explicit about the ethical and aesthetic implication of the reader in what is read and the relations among fiction, figuration, narrative, and history. ${ }^{8}$ The reader of the Heptaméron cannot speak and act within the tale as Bernage does, but Bernage nevertheless invites the reader to consider how to respond in historical terms to aesthetic and fictional forms.

Heptaméron 32 is brief. A messenger of King Charles VIII, Bernage, knocks at a German castle. Reluctantly, the servants let him in, and the lord of the castle explains that he keeps the door locked because he is at odds with his wife's relatives. The two men sit down to a meal. A beautiful woman with a shaven head silently comes out from behind a tapestry, silently washes her hands, eats a little, drinks from a cup made of a skull with the eye holes filled 
with silver, and silently retreats. The lord of the castle offers to explain, and tells Bernage that after marrying his wife against the will of her family, he caught her in an act of adultery and killed her lover. He imprisoned his wife in her bedchamber and put her lover's skeleton in her armoire. He lets her out only for meals, when she drinks out of her lover's skull. The host offers to take Bernage to the woman, and they go into her room, where, with the host's permission, Bernage asks her a few questions. She is uncomplaining, but subdued. After leaving the room, Bernage suggests to the host that he should consider forgiving his wife. The king sends his painter, Jean de Paris, to paint a picture of this beautiful shaven woman. Sometime later husband and wife resume marital life and have "beaucoup de beaulx enfants" (p. 245).

Bernage's interest in the wife and his desire to know her story enacts within the borders of the tale the reader's desire to know. The reader's pleasure comes both from the disturbing visual spectacle of this beautiful woman with the macabre ornaments created by her husband, on the one hand, and, on the other, from the narrative movement, that is, the revelation of the meaning behind the events first witnessed by Bernage and the breaking of the confined cycle of these events through the telling of this story to an outsider and the outsider's response. The narrator, Oisille, sets up the woman as a source of visual pleasure for Bernage and for the reader. The woman, who first appears from behind a tapestry (an art object itself), is "la plus belle qu'il estoit possible de regarder" (p. 242). As François Rigolot points out, the woman's shaved head echoes the skull she drinks from. This doubling heightens the aesthetic pleasure experienced by the reader. And it implies that not only the skull cup but also the woman's head is an "esmerveillable vaisseau" (ibid.). In other words, the aestheticization of the skull cup bleeds onto the woman. The husband has, in a sense, treated his wife as the material from which to make art. His punishment involves an unnecessarily ingenious and aesthetic arrangement of elements. The husband hangs the lover's body in the "armoyre" in the room where the wife had made love with her lover, "tenduz comme chose pretieuse en ung cabinet" (p. 244), the word "cabinet" suggesting a "cabinet de curiosités," where rare objects were placed for display and contemplation. The eyes in the skull are filled with silver. The wife's association with the bones is metonymic (she puts the bones to her lips) and analogic (the skeleton in the armoire corresponds to the woman in the room). And the husband's interpretation of the moving, silent tableau, told in the form of a story to Bernage, is also a confinement, in the sense that it does not acknowledge the wife's possible divergent perspective.

Bernage paradoxically appears both as a healing witness and as a voyeur whose interest in the woman has erotic connotations. While none of the devisants take the woman as an erotic object, Bernage does make this move 
to some degree: he finds her extraordinarily beautiful, he wants to go into her chamber, and he wants to talk to her. Talking in the Heptaméron often leads to seduction or reveals desire. ${ }^{9}$ And indeed Bernage's curiosity itself is a form of desire, though it is mediated through narrative and not, like adultery, experienced in the body. The stress in the tale on the lady's beauty, of which Bernage is the first witness, reminds the reader that we too are enjoying looking over the shoulder of Bernage at this spectacle. As the novella is interested in the question of aesthetics - how does one evaluate artistic or aesthetic beauty in a story that tells of the dangerous power of physical beauty? - the readers and Bernage are faced with the question of whether our desire to see this representation, like the king's desire to have a portrait painted later in the story, is not itself a form of intrusion, a movement into the lady's private suffering that may be at least in part voyeuristic.

This reading is additionally supported by the degree to which the novella, following Marguerite's form in other related stories (notably Heptaméron 4 and 10), identifies the woman's chamber as a symbolic representation of her self and especially her body, a characteristic play between literality and figuration within this short narrative. ${ }^{10}$ If the lover's head can become a literal cup which echoes the wife's shaved skull, her room can metaphorically evoke her body. In this reading, when the husband puts the skeleton in his wife's armoire he figuratively puts death in her womb, indicating what he feels she has done to their future and suggesting why it will be so hard for them both to escape from this impasse. The punishment he metes out, which involves controlling her every physical move and restraining her as though she were an object, then also becomes a figurative rape of the wife by the husband, a rape that paradoxically places death inside her, and heightens the symbolic violence of the husband's punishment. ${ }^{11}$

By entering the room where the adultery was committed and talking to the wife, Bernage invades her space and enters her privacy, and so repeats on a figurative level the act of adultery. But by doing this with the permission of the husband and by seeking to know her story rather than to have her body, Bernage allows the husband to work through the trauma of the adultery. The healing act mimes the adultery, but without the woman's body being further tainted, and with the husband's consent. The husband then is ready to listen to Bernage's humane suggestion. The unsealing of the woman from the cell comes about through Bernage's response to image, story and the flesh-andblood woman who has submitted to the conditions of the story. This response includes personal (and possibly erotic) interest and compassion. ${ }^{12}$ In contrast to the husband's sadistic treatment of his wife, Bernage's interest and his desire to hear the lady speak break the spell of traumatic repetition. 
Bernage's status as a reader/interpreter develops the role of his antecedent in the most probable source for Heptaméron 32, exemplum 54 of Le Violier des Histoires Rommaines (the sixteenth-century French translation of the Gesta Romanorum). ${ }^{13}$ In the Violier, the Bernage figure is both a merchant who is invited into a seigneur's house because he envies the seigneur's happiness and, in the one-to-one allegorical "moralisation" that follows the tale, the confessor who visits the good Christian's heart. At dinner, the merchant sees the wife drinking out of the skull, and fears for his own safety, thinking, “j'ay grant paour de perdre la teste dedans ce lieu." 14 After dinner, alone in his bed, the merchant "apperceut au coing ou estoit la lumière deux hommes mors pendans par les bras." 15 The dead men, he learns in the morning, are cousins killed by the brother of the wife's lover in revenge for the husband's killing of the lover. According to the moralisation, the prince is the good Christian, and the hanging men are the pleasure in God and neighbor which original sin has killed. Both reader of the Christian's heart and participant in a narrative, the confessor/merchant is personally implicated in the story: his fear of the skull and the hanging men, as he visits the heart of the troubled "good Christian," demonstrate that "reading" the Christian's heart involves some risk. The confessor/merchant feels fear for his own safety, whereas Bernage responds to the lady's beauty. For both figures, effective witnessing is the opposite of detachment. This kind of witnessing promotes mutual recognition of vulnerability and has the power to transform both viewer and viewed, reader and read. As a model of reading, it is personal and particular (each exchange has its own time, place, and participating subjects with their own histories, prejudices, and goals), and it can effect both internal transformation and relations between people. Even though both Bernage and the confessor/merchant represent powerful authority structures (the king and the Church, respectively), their intervention involves a kind of personal risk.

Unlike the husband, the lover and the adulterous wife, stock characters of fabliaux and romance, Bernage has a name. And like Charles VIII and the painter, Jean de Paris, he corresponds to an historical personage. ${ }^{16}$ The fact that the stock characters appear in the story without names, while the witness figure, the king, and the painter are all specifically named historical figures, helps to dramatize the collision between literary expectation and historical factuality. The traumatic repetition of sterile punishment and grief appears at the beginning of the tale in terms that are heavily marked with generic references to romance, such as the setting in a strange castle that is initially barred to outsiders and the ritualized spectacle within the castle, including a mysterious woman and a mysterious cup. It is as if Bernage stumbles on a frozen, generically bound story, which has been existing out of time, and 
reintroduces the characters to the historical world. The movement towards history at the end of the tale suggests that values and lessons can be imported from the world of literature into human life. The reader is aligned with history, with Bernage, both because Bernage is a visitor from the realm of history and because Bernage's curiosity stands for the reader's.

At the end of the story, the wife's repetitive existence, frozen in the moment of her punishment, is split into two: a woman living on in a narrative that gives her many beautiful children, and the painting by the king's painter, a still image. Picking up the comments of Ennasuite, François Rigolot has connected the iconography of the story to the repentant Magdalen. The latter is often pictured cutting off her hair, and Rigolot also identifies a moment in Marguerite's life when she could have seen a relic of the Magdalen's skull: in 1516 the princess visited the Magdalen's shrine at Saint-Maximin, near Marseilles, with her mother and brother. ${ }^{17}$ Rigolot comments that "the King's intervention [in requesting the portrait] is a clear signal that the penitent sinner should not be despised out of self-righteousness." 18 In this reading, the portrait signifies both the lady's guilt and her forgiveness, and the skull becomes more a sign pointing to the figure of a penitent saint than a materially embodied means of psychological torture. Rigolot concludes that "the powerful thrust of iconography is never used to force an allegorical interpretation," 19 but in order to highlight the penitential meaning of the story, he de-emphasizes both the husband's rage and the constraints the husband places on the woman.

Yet the painting can also be read as the concrete aestheticizing of a woman's suffering. ${ }^{20}$ The painting is a picture of a woman frozen in time, so that she can be owned and displayed at will, and the wife in the story has been much like this image from the moment her husband imprisoned her. The painting memorializes the woman's punishment, and when her punishment is seen as an aesthetic project of her husband's, the painting can be seen as the final step of his enclosure of her. The painting crystallizes a representation of this lady as beautiful and submissive to her husband's authority, and it potentially aligns the husband's authority with spiritual rectitude. Indeed, Marguerite's devisants do not criticize the husband. But because the woman appears silent and still in the frame, the painting also highlights the fact that we never hear the woman speak, except briefly, while she is still imprisoned and in her husband's hearing. ${ }^{21}$ Framed by the king's approval, the painting can raise the question: what is silenced when readers accept the husband's authority?

The complex positioning of the reader, with Bernage, as curious participant and transformative witness, goes well beyond the imbibing of moral precepts, and it also goes beyond a simple recreative pleasure. Bernage is 
deeply implicated in the result of the tale, both as healing witness and as a link in the chain that leads to the production of the picture. His witnessing spreads the story of the lady's shame more widely but also opens the door of her prison and allows her to return to a normal life. His beneficial effect is possible because of his deep interest in the lady, both his desire to learn her story and his appreciation of her beauty. This interest, aligned with the reader's interest, ultimately leads to the production of the picture, with its double import as certification of forgiveness and as an aesthetic reification of conditions of gendered violence. The roles of the voyeur who takes pleasure in looking and the ethical witness whose looking shifts the destructive pattern turn out to be intertwined. The reader is called upon both to desire (beauty and information) and to witness and respond with action to the suffering represented. Since the reader cannot act directly within Heptaméron 32 itself, the reader's response must occur in the historical world — through action, the production of commentary, or the production of further narrative.

Bernage is male, and I have been arguing that Bernage's symbolic reenactment of adultery helps the husband to work through his anger. Yet the implied reader for this tale is not exclusively male. The devisants of the frame tale, who offer a second model of reading and who, like Bernage, are inscribed interpreters, use gender as a category of analysis, frequently remarking on differences between men and women. For example, at the end of Heptaméron 26, Parlamente tells Hircan, "si nous pechons par orgueil, nul tiers n'en a dommage. . . . Mais vostre plaisir gist à deshonorer les femmes, et vostre honneur à tuer les hommes en guerre" (p. 221). If one emphasizes the gender of the reader, Heptaméron 32 outlines particular risks for a male reader (he might fall directly into desiring the lady and miss the opportunity to shift the repetitive grief of the marriage), as well as a particular opportunity: a female visitor to the castle would not have functioned in the same way. Female readers might identify less with Bernage's male perspective either as desirer or as messenger of kingly authority, and thus might move more quickly to reflect on the practice of reading and to see the concluding portrait as a form of internal, unacknowledged commentary on the aestheticization of suffering and the stilling of the woman's voice in the novella itself. Nevertheless, while it might be tempting to imagine a more overtly feminist reading being articulated silently by the female devisants, especially as they make comments critical of gendered violence in discussions following other, related tales, the story's model of effective witnessing, which involves personal engagement and perhaps some spiritual risk, works for either a male or a female reader. And although the particularities of this tale involve a male reader-figure and the representation of gendered violence, its messages that reading brings into the realm of history meanings 
shaped by generic and fictional forms, and that reading invites intertwined ethical and aesthetic engagement, apply to readers of both genders.

Even though there is no female figure for the reader inscribed within the tale itself, the female devisants offer the key points in the discussion following the tale. Significantly, they respond in a measured, thoughtful register, analyzing the ethical import of the tale. ${ }^{22}$ For Oisille, the skull of Heptaméron 32 acts as a revelatory device, indicting the wife's bad behavior. Oisille also suggests that many more women would be drinking out of skulls, if truth were told, and that women should not trust in their own insufficient spiritual strength. Colette Winn, following Oisille, sees Heptaméron 32 as a story about disciplining the body. Partaking of the "corps prison de l'âme" motif, the story would thus argue that the woman, having been led astray by bodily lust, must learn that the body is not the true source of happiness. ${ }^{23}$ Beginning with the gruesome rape and murder of the muleteer's wife (Heptaméron 2), Oisille frequently tells stories in which she deploys vividly embodied, gendered violence to illustrate spiritual principles. ${ }^{24}$ Though Oisille never criticizes the husband of Heptaméron 32, the repeated gendering of violence in Oisille's tales throughout the Heptaméron is striking.

Parlamente, whom many scholars have seen as a figure for Marguerite de Navarre herself, similarly upholds the husband's punishment ("tout ainsy que l'offence est pire que la mort, aussy est la pugnition pire que la mort" [p. 245]), though she does state her approval using potentially equivocal phrasing: the punishment is "autant raisonnable qu'il est possible" (ibid.). Because of her desire to uphold female honour, Parlamente cannot appear to countenance the wife's adultery. This constraint would make it difficult for her to criticize the husband. ${ }^{25}$

Cathleen Bauschatz argues persuasively that Marguerite de Navarre reworks Boccaccio's dedication of the Decameron to "fairest ladies" in order to "develop — and test - the implications of this convention," 26 and she shows that the devisantes frequently "reinterpret who the central character is, and what the central action involves," 27 as they evaluate the exemplarity of the female characters and take stock of the didactic message that male narrators offer. Longarine's and Ennasuite's contributions to the discussion fit into this pattern, as they consider how to act in the lady's position: Longarine says that it is better to die than lose honour, while Ennasuite states that she would prefer to live and repent. Two male speakers then criticize the woman's behavior, Dagoucin suggesting that the woman should have died of grief when she saw her dead lover, and Simontaut saying that all women are faithless anyway. Nomerfide flirtatiously mocks Dagoucin's idealism, and the discussion ends rather inconclusively, as do most of the discussions in the Heptaméron, with the choice of the next story-teller. 
While Oisille and Parlamente are authoritative voices, emphasizing disapproval of adultery and the human folly of trying to stand alone without God's help, a specific position on the meaning of the tale does not emerge. The tale's portrayal of spiritual crisis, physical and symbolic violence in marriage, and of feminine beauty, leaves its inscribed listeners in a state of some disagreement, highlighting their separateness and individual interiority, even as they participate in the group discussion.

I have argued that the painting in Heptaméron 32 opens questions about gendered violence, about the role of fiction and art in shaping history, and about the reader's interpretive responsibility - questions that none of the devisants recognize explicitly, but that are implicit in their divergent discussion. Similarly, these questions are never acknowledged directly by the sixteenth-century English adaptors of the tale. George Whetstone, in particular, wrenches aspects of Marguerite's tale away from its implications, as he uses it to defend marriage. Both Whetstone and William Painter were, of course, male readers, and English court ladies and bourgeois wives have left little record of their responses to their reading or hearing of such fictions, neither marking their books nor writing their own collections of similar narratives. ${ }^{28}$ Yet in their versions of Heptaméron 32, Painter includes and Whetstone focuses on and reshapes the aesthetic intensity of the figure of the enclosed wife. Painter and Whetstone respond in their own ways to the entwined aesthetic and ethical claims of the tale, and, as they do so, they re-imagine the community of listener-readers found in European novella collections.

Both Painter and Whetstone wrote simultaneously for patrons and for unknown readers, who could purchase their books from a bookseller, and their double dedications reflect their double audiences. Both works could have been circulated in manuscript before being printed (Marguerite de Navarre's Heptaméron and many English lyric collections certainly were), and it is likely that the tales they include in their collections were told orally in both elite and non-elite gatherings. ${ }^{29}$ The discussants found in novella collections, with their relatively homogeneous material circumstances and their friendly acquaintance, are perhaps similar to the people who might have circulated stories in manuscript, read them aloud, or told them to each other face to face. But once the stories were sold by booksellers, this "community" was imaginatively extended. Prefaces and epistles offered the writer or bookseller a chance to attempt to direct the reader's attention and to set the terms for reading the book. ${ }^{30}$ As Wendy Wall has argued, prefaces to printed works were often fraught with concerns about maintaining social distinctions, and often used an axis of gender to recode anxieties about class. ${ }^{31}$ Casting out their books as orphaned children or vulnerable women, such 
prefaces imagined the "community" of readers as male and called upon their charity, as well as enticing them. But Painter's and Whetstone's prefaces, and particularly Whetstone's frame tale, imagine the "community" of readers more like the group found in a novella frame tale, a group including both male and female readers who read for entertainment and to debate ideas and norms. ${ }^{32}$

Painter's Palace of Pleasure touched off a vogue for novellas in Elizabethan England with its two volumes containing a hundred-and-one tales, including French and Italian novellas alongside classical histories and fictions, and its prefatory material, which imagined reading as a civil conversation. In praising Ambrose Dudley, Earl of Warwick, General of Her Majesty's Ordinance and Painter's superior, to whom the first tome of his Palace of Pleasure is dedicated, Painter writes, "Who is he that more condignelye doth deserue to be possesst in a Palace of Pleasure, than he that is daily resiant in a Palace of renowmed fame, guided by a Queen adorned with most excellent beautie indued and garnished with great learning, passing vertues and rare qualities of the minde" (1: 6)..$^{33}$ In the introduction to the second tome, Painter again calls the book "a very Court and Palace" (2: 157). Painter, who as a clerk of the Ordinance in the Tower of London did not frequent Elizabeth's court, claims that his book is analogous to and commensurable in some way with Elizabeth's real court. Painter's title, The Palace of Pleasure, alludes to the ideal retreats in the frame tale of the Decameron and, more generally, claims to represent courtliness. In place of the fully imagined ideal courts of the European frame tales, which exist in contrast to the disordered world of plague or flood outside their confines, Painter offers a shared social experience imagined through the medium of reading the printed book.

Painter also makes a remarkably status-blind claim about the appeal of his book. In his address "To the Reader" of the second tome, he says, "To be short, the contentes of these Nouels from degre of highest Emperour, from state of greattest Quene and lady, to the homelye Cuntry peasant and rudest vilage girle, may conduce profite for instruction, and pleasure for delight. They offer rules for avoiding of vice and imitation of vertue to all estates" (ibid.). This blithe claim to universality contrasts with the "fears about collapse of social difference" that appear in many early modern printed works, and also with the frequent dedication of novellas (with romances and courtly love poetry) to ladies. ${ }^{34}$ In the address "To the Reader" of tome one, Painter also invites the reader to "Injoy with [Ambrose Dudley, Earl of Warwick] this present booke" (1: 10), and while explicitly including the "greattest Quene" among his potential readers, he claims to write both for a network of patrons and for the marketplace, for male and female readers, for 
rich and poor; that is, he does not seem to exhibit anxiety about maintaining class distinctions or a tendency to gender his text as female. Through the figure of the palace and the claim that the stories are broadly applicable, Painter offers his most humble readers access to the figurative wealth and pleasure and status of his virtual "palace." In brief, Painter modifies the inherited framing tradition by conveying aspects of the fictional court through his "Palace" title and his introductory commentary. He extends a vicarious experience of courtly civility to all the readers of his book. ${ }^{35}$

The ethical position of the reader within this vicarious courtly society is complicated. With no discussants at all and infrequent authorial commentary appearing within or following individual tales, ${ }^{36}$ the reader's primary guidance as to how to respond comes from the introductions, dedications, and epistles to the two volumes. In this prefatory material, Painter claims that his stories are morally instructive, but in doing so, he often places the responsibility for correct interpretation on the reader. He assures Warwick,

although by the first face and view, some of these may seeme to intreat of vnlawfull Loue, and the foule practises of the same, yet being throughly reade and well considered, both old and yonge may learne how to auoyde the ruine, ouerthrow, inconuenience, and displeasure, that lasciuious desire and wanton wil doth bring to their suters and pursuers. All which maye render good examples, the best to be followed, and the worst to be auoyded. (1:5)

The reader is responsible for reading thoroughly and considering well, and in spite of what Painter implies, this engagement must go beyond accepting and rejecting examples. ${ }^{37}$ For example, in "Aristotimus the tyrant," as Micca prays to her father that he not deliver her to the tyrant, Lucius, the tyrant's henchman,

began furiously to hale hir by the garments, vpon whose struggling he tare hir kirtle and furnitures of hir head and shoulders, that hir alablaster necke and bosome appeared naked, and without compassion tare and whipte hir flesh on euery side, as the bloud ranne downe, beating that tendre flesh of hirs with manifold and greuous blowes. (2: 210-11)

Painter comments, "O vile tirant, more wood and sauage than the desert beast or mountaine Tigre: could cruelty be so deepely rooted in the hart of man which by nature is affected with reason's instinct, as without pity to lay handes, and violently to hurt the tendre body of a harmlesse Maidee? Can such inhumanity harbor in any that beareth about him the shape of man?" (2: 211). The statement that such behavior is inhuman is overshadowed, however, by the voyeuristic description of the woman's alabaster neck and naked bosom, which places the reader(whether male or female) in a more 
compromising position than Painter acknowledges here. As a reader, Painter himself seems to have responded to the beauty of the woman's white skin and to have imagined her "tendre body." By combining this sensual description with a moral appeal to humanity, Painter enacts a form of the dual response that Bernage makes to the enclosed lady in Heptaméron 32. But whereas Marguerite's tale points to the entwining of desire, beauty, and ethical response within her tale, Painter does not articulate the same awareness here.

In another example, "A Duke of Venice and Ricciardo" (tale 48 in the first volume of The Palace of Pleasure), Ricciardo, son of Bindo the architect, escapes punishment for stealing from the Duke's treasure-house by outwitting the Duke in a series of tests. In the last test, the Duke puts his daughter in the middle of the room and leaves a group of suspects in the room with her overnight. If any of them comes to kiss her or seduce her, she is to mark his face with black. After seducing the daughter, Ricciardo marks all the men's faces with black, thus implying that she has had sex with all of them and hiding his own success. The king laughs and asks who has done this, and Ricciardo confesses and gets to marry the daughter. Of this story about a trickster figure whose unremitting boldness in murder and seduction makes him heir to a dukedom, Painter says, "If the artificer will not faithfully deale according to the truste reposed in him, I would not wyshe him to suffer that whiche Bindo did, but aduisedly to reade the Historie, and trustelye to accomplishe that he taketh in hande" (1: 12). Painter is engaged in accounting for the moral utility of the tale, yet his account is markedly insufficient. He ignores the main point of his story, Ricciardo's unpunished wit and insubordination, and instead advises servants to be loyal and "trusty." The reader's response to the tale will certainly exceed the moral Painter suggests. It is even possible that Painter was deliberately obtuse about the pleasures that these stories could offer, choosing to justify them as morally useful because of the humanistic expectation that reading should be so. ${ }^{38}$

The reader receives little direct guidance from Painter in interpreting his translation of Heptaméron 32. The translation appears in the Palace of Pleasure as the fifty-seventh novel, with the title, "A punishment more rigorous than death, of a husband towarde his wife that had committed adulterie." Painter provides no further commentary on the tale, and he does not include the devisants' discussion. The reader may therefore fall back on the general advice given to the reader in his prefaces and epistles. For instance, Painter suggests that women will find in his book models of true chastity and have their loyalty to their husbands reinforced, and that men will learn not to be lustful, violent, or dissatisfied with their lot in life. $\mathrm{He}$ claims that his stories are profitable: "Profitable, I say, in that they do reueale 
the miseries of rapes and fleshly actions, the ouerthrow of noble men and Princes by disordered gouernment, the tragical ends of them that vnhappely do attempt practices vicious and horrible" (1: 11). He also claims that the stories have a recreative, healthful, pleasurable quality.

To apply Painter's initial claims about his stories to Heptaméron 32, he is right that the story makes an ethical appeal, but he oversimplifies the mechanism of this appeal. As I read the tale, the husband's enclosure of the wife is too closely linked to a pattern of gendered violence to be a stable "disciplining" of an unruly female subject, and taking pleasure in the tale is uncomfortably close to taking pleasure in the woman's suffering. The aestheticized torture of the lady, together with the portrait created at the end of the tale, speaks hauntingly to this interpretation, though it is never articulated directly. Witnessing is not simple either. Bernage's witnessing can be read both as an attenuated reenactment of the adultery and as a step in the release of the woman. It also leads to the publication of her story. The relationship between the more genre-bound, unnamed characters - the lover, the husband, and the wife - and the named and historical Bernage, whose action brings the complex ideological meanings of the portrait out of the household (where both the husband and the wife are trapped) and into the national realm, out of the genre and into the realm of history, echoes the reader's relationship to a work of fiction in Painter's Palace: the story is telling the reader that the reader is, like Bernage, a vector for the movement of meanings from tales to the realm of action. As in the Heptaméron itself, Painter's translation thus constructs the reader, not as a passive recipient of meanings, but as an ethically implicated, active interpreter. Though this is not explicitly stated in his epistles, English readers invited into Painter's Palace could find in this story a model of reading that goes beyond accepting or rejecting examples, that highlights the reader him or herself as an active conveyer and producer of values, and that privileges both individual interiority and social exchange.

In contrast to Painter's Palace, Whetstone's Heptameron of Civil Discourses has an elaborate frame tale, which places Marguerite's story in the context of a courtly discussion of marriage during Christmas festivities at the house of an Italian gentleman Whetstone calls Segnior Phyloxenus. Though the frame tale is set in a remote location during a festive time, Whetstone insistently links the idealized characters of the frame with the readers of his Heptameron. In his dedication of his Heptameron to Christopher Hatton, Whetstone explicitly hopes that these exercises "may be a president of behauiours to the indifferent well qualited Gentleman and Gentlewoman," and in his epistle "unto the friendly reader" he reiterates the hope that readers will model themselves on the discussants he portrays. ${ }^{39}$ 
Whetstone also blends the worlds of his idealized discussants and the reader by including among the commendatory verses a verse "deliuered by VRANIE, with a Siluer Pen, to ISMARITO, in a Deuice, contayned in the seuenth daies Exercise: placed in this Forefront, for the excellencie of PANDORA" $\left(\operatorname{sig} .{ }^{*} \mathrm{v}^{v}\right)$. Ismarito is the English traveller Whetstone identifies with himself, who participates in and reports the story-telling scene, and his appearance in material that is prefatory to the book as a whole invites the reader to shift frames and to enter more fully into the discussions.

Whetstone read widely in novella collections, as is shown by his use in his Heptameron of the Decameron, the Heptaméron, the novellas of Pedro de Mexía and Giambattista Giraldi (Cinthio), and Painter's Palace. Within the Heptameron of Civill Discourses, Ismarito is found one morning reading "Peter Mesiere his Chronicle of Memorable Things" (sig. Riv ${ }^{r}$, and his host Signor Philoxenus declines to interrupt him, "seeing the great personages with whom you devise" (sig. Rivv). By imagining the act of reading Mexía's stories as "devising," a word whose sixteenth-century meanings encompassed conversation, planning, and both practical and mental inventing and framing, Philoxenus suggests that such reading is an intellectually constructive conversation. Thus Whetstone within his text portrays both the oral narration of novellas and the reading of novella collections as productive exchanges of ideas.

Seven novellas appear within the frame tale of an imaginary court, which Whetstone modeled upon the utopian government of Boccaccio's Decameron and the provisional court of Marguerite's Heptaméron. ${ }^{40}$ Ismarito is welcomed hospitably to a palace within an Italian wood. The great hall of the palace is hung with the device of the host Signior Philoxenus,

which was A Holly Tree, full of red Beries: and in the same, a fluttering MAVIS fast limed to the bowes, with this posie in French, Qui me nourit, me destruit: And, in verie deed, the beries of the tree feedeth this Bird, and the barke maketh Lime to fetter her. But I afterwardes learned, Segnior Philoxenus used the Ensigne as a covert description of desire: whose sweete torments nourisheth the minde, but consumeth the bodie to the grave. (sig. Bii)

In an inclusive gesture, Whetstone interprets the device for his readers, effectively extending the hospitality of the fictional court.

In the conversations and pastimes of Whetstone's idealized court, the channeling of erotic energies into appropriate marriage is a major preoccupation. On the seventh day, after six days have been dedicated to the inconveniences of marriage, the solution Signior Philoxenus proposes is that marriages should match "fancie" and "foresight." The civil subject who wants to get married should ideally base her or his desire on both of these 
rhetorically opposed principles. Desire must focus on status without appearing to focus on status: the well brought-up citizen will freely choose the partner of appropriate social status. ${ }^{41}$

The stories are in theory told primarily to illustrate points made in the argument about marriage. Yet the reading of the stories does not always or only produce an allegory of virtue. For example, Ismarito tells a story in which the young Rinautus is loved by Circe, a "wrinkled, ill favoured witch" $\left(\right.$ sig. $\mathrm{Ti}^{\mathrm{v}}$ ), but because he will not return her love, she turns him into a rhinoceros. He still hates her, and he kills everyone he meets in order to be revenged:

Yet is he by this policie subdued: Place a faire Maide, in his walke, and foorth with hee will with a lovinge countenance, repaire unto her, and in her bosome, gently bestow his murthering Horne: and sodainlye, (as one ravished with contentment) hee fauleth a sleepe, by which means he is slaine before he recovereth the use of his force. ( $\operatorname{sig} . \mathrm{Tiir}^{\mathrm{r}}$ )

The response of the company to this sleeping rhinoceros, symbol of sexual exhaustion, is not one of moral righteousness; instead, "the Companie laughed well, to heare this straunge Metamorphosis" (ibid.). Nevertheless, for the most part, the company's method of reading is to abstract the moral principle of the tale and invite the readers or listeners to apply it to their lives. Less open-ended than the discussions of Marguerite's devisants, these tales model levels of disagreement for a reader and provide conclusions to the moral and practical questions raised.

Whetstone's adaptation of Heptaméron 32 shows that he responded as a reader to an ethical claim within the tale, since he includes it within his larger discussion of the rights and wrongs of marriage. But by defining the moral meaning of the tale more closely than either Marguerite or Painter, and also by rewriting some important details, Whetstone's version changes the way in which the tale addresses the reader. The tale is told on the third day, a day "Contayning: sundrie Morall Preceptes: With a large Discoverie, of the inconveniences of Rash Mariages" (sig. Hiir ${ }^{r}$, by Doctor Mossenigo, a curmudgeonly figure who tends to speak against women and who is described by Whetstone as "A Germaine, so called, for the plaine discouerie of his mind" (sig. Cir). Entitled "The Historie in reproofe of rash Mariages, reported by Doctor Mossenigo" (sig. Kir), the tale forms part of Dr. Mossenigo's argument against free choice in marriage (that is, against marriage based on youthful affection rather than parental guidance).

From the beginning, the marriage is presented as unequal, the lady, Felice, being poorer than the gentleman, Malipiero. Before marrying, Malipiero asks a respected older man for advice, and the man responds with 
misogynistic commonplaces to the effect that beautiful women are expensive and unchaste. When Malipiero marries Felice, his family disowns him, and the couple faces poverty. Whereas in Marguerite's tale the illicit love affair is a given from which the dynamics of witnessing and the working through of trauma proceed, in Whetstone's version considerable attention is devoted to the seduction: the tale details an exchange of letters between Felice and the lover figure, Marino Georgio, with several love letters reproduced in the text, and once the affair is established, the narrator comments that "this Conquerour Gowlde, made suche a passage, into a reputed honest Cytizens house, as, without suspition, Marino Georgio, and fayre Felice, theare (many tymes) mette" (and the side note helpfully adds, "Gold maketh passage into difficulte places") (sig. Lir). The setting of the story is urban and social, unlike the isolated medieval castle of Marguerite's tale, and there is no concluding painting.

Whetstone's tale transfers the ornamentation of the silvered skull that the lady drinks from in the Heptaméron to a token used to seduce the lady. In Whetstone's version, once the lover has been killed, the lady still has to drink out of his skull, but it is not ornamented with silver. Instead, early in the progress of their affair, Marino Georgio, who falls in love with Felice after seeing her in the marketplace, sends Felice

the Image of himselfe in Goulde, inameled blacke, his face meager and pale, and by a device, the blacke mantell throwne aside, for to appeare, the bared Carkasse of Death, with the intrayles consumed, and in the seate of his lyfe, to place Felice, attired with Diamonds, Rubyes, Emrodes, and other precious Stones, looking upon his smoking harte. (sig. Kiv ${ }^{r}$ )

This image of the tortured wooer is also an object of monetary value, intended to seduce. It emphasizes the lady's power and at the same time implies that she is vulnerable to financial persuasion. The image presents Felice as already being inside the lover's interior self, already seeing and knowing his innermost love, and made richer by this vision. Tracing the description of this jewel-bribe, the reader's gaze is directed first at the wasted lover, then at the richly attired lady, and finally at the lady's looking on the lover's heart. Whereas in Marguerite's tale, the reader's gaze is directed, with that of Bernage, toward the lady's beauty and suffering, and perhaps also toward Bernage and the reader's own looking, Whetstone's jewel argues for the dangerous power of the lady's look. The later scene of the lady drinking from the lover's skull can therefore be read as an extension of her triumph over his body as represented in the jewel. The portrait in Marguerite's tale graphically draws attention to the process of making beauty from suffering, underlines the lady's near silence, and serves as a 
model within the novella of the potential for movement between the realm of art and the realm of history that can also occur through reading the novella itself. By replacing the portrait with another aesthetic object, the jewel, Whetstone registers the importance of the portrait in the first tale, while avoiding these meanings, and thereby demonstrates that there was something indigestible for him about the combination of the torture scene and the painting in Heptaméron 32. Whetstone transfers the focus from the lady's suffering to the lover's, reframing the husband's torture of his wife in a scenario of courtly love gone wrong, where the powerful lady cannibalizes her admirer's wasted frame. Whetstone's didactic concern with defining and promoting orderly Protestant marriage leads him to diminish the original tale's aesthetic elaboration of the tortured lady, while his interest in courtly seduction and the lover's vulnerability finds expression in the jewel. The jewel also functions as a symbol of the blending of materialism and love that Whetstone advocates, in which prospective marriage partners should love persons of appropriate wealth (matching their emotions with material offerings). As in Heptaméron 32, the ornate aesthetic object points to an otherwise unacknowledged problem in the narrative.

Whetstone's version de-emphasizes the bizarre ingenuity and timelessness of the punishment and the powerful intervention of the witness. Whereas in Marguerite's tale the witness figure was a representative of history, Whetstone's witness, Segnior Cornaro, remains generically bound. Unlike Bernage, Cornaro is not the messenger of an historical king, and indeed, the name Cornaro suggests horns, allying this counselor with cuckoldry. In contrast to Bernage's sober and serious advice to the husband, Cornaro's suggestion that the lady should be released is described as "intreating" and takes effect immediately, with no portrait being painted.

These alterations transform the tale's address to its reader, as they make the story's resolution more immediate, weaken the links between the witness figure and the reader, and shift the levels of figuration in the story (since there is no painting and the comparison between the lady's bald head and the skull she drinks from is less pronounced). In addition, the discussants tidily sew up the meaning of the tale. Fabritio, an "elderly courtier" (sig. $\mathrm{Ci}^{\mathrm{r}}$ ), says,

Maister Doctor, you have reported a very necessary history: for it containeth many heedful notes, both of Admonition and advice. Besides the due punishment of rashness in Marriage. For therein we may see how hungerstarved want, compelleth the best natured man to deceive his friend, and yield to his own slander. Again, how that monster Gold, conquereth the honor of the fairest. (sig. Liiir) 
Fabritio thus obediently echoes the cues given to the reader through the sidenotes of the printed text, emphasizing the problems of poverty and unequal wealth, and blaming women for their materialism. The second speaker, Isabella, defends women, pointing out that men can also be seduced by gold. Soranso and the queen of the festivities, Aurelia, address the exemplarity of the tale, Soranso repeating Oisille's notion that "if euery lyke offence were so sharpely punnished, we should haue Mazers of mens Sculles, more ordinarye then Siluer Boules, and powled Women more common then baulde men" (ibid.), and Queen Aurelia arguing that this punishment would be useful in deterring adulterers. There is some divergence along gender lines, as Whetstone borrows the model of inscribed listeners analyzing the social significance of the fiction. But in general the discussants agree on the meaning of the story, and the narrator describes their activity as the culling of "Morall notes" (ibid.). In the larger context of the book, whose seven days of discussion are all at least ostensibly devoted to organizing erotic desire into appropriate marriages, this commentary threatens to limit the readings of the tale. Whereas Marguerite's tale models a flexible distinction between fiction (the generically bound characters who enact their repetitious torture in the castle) and history (Bernage, the king, and the painter), with the result of somewhat equivocally celebrating the intervention of history into the fictional realm and emphasizing the reader's responsibility, Whetstone's version criticizes avarice and unequal marriage, celebrating the direct usefulness in social life of "moral notes" from fiction.

Neither Marguerite de Navarre's devisants, nor Painter, nor Whetstone interpret Heptaméron 32 as this essay argues the tale asks its reader to do, though Whetstone's addition of the tortured jewel as a tool of seduction suggests that he has responded to the erotic and aesthetic aspects of the lady's imprisonment, and his recommendations for marriage suggest that he saw the tale as having an ethical impact. Painter's telling of the story without any comment may allow the reader to identify more directly with Bernage, since there are no discussants in his Palace. The fact that Marguerite's devisants and the sixteenth-century translator-adaptors do not comment on Bernage's role or directly critique the husband's treatment of his wife need not, however, diminish the importance of these aspects of the tale. The English translations that survive from the sixteenth century represent only two interpretations by sixteenth-century male readers, and many more responses went unrecorded. Moreover, since the readers of the novella remain outside the frame even of the implied author and his patron, our readings remain on a different plane from theirs, and even more powerfully outside the frame of reference of the inscribed discussants, who finally remain figures within a fiction. 
I have suggested that Bernage is a figure for the reader and that the reader is thereby made aware of his or her own involvement in an ongoing construction of meaning, which crosses back and forth between the realm of fiction and that of history; that the reader is called to respond actively to the violence represented (in this case the violence of a dysfunctional marriage); and that ethical response is revealed to be intertwined with aesthetic engagement and with personal risk (such as the risk of inappropriate sexual desire or fear for personal safety). It makes sense that these ideas are implicit in the story rather than explicit. Because the story is in part about movements among history, narrative genre, and figures or symbols, it is about both the encoding of norms in artistic form and the potential of artistic form to register the suppression of alternative possible meanings (as the painting in part registers the suppression of the lady's voice) as well as to intervene in history (since the process of making the painting and letting it become famous, with Bernage's testimony, may have helped to free the lady from her bony chamber). Such a message about processes of figuration and meaning-making is not likely to be expressed explicitly. Yet the frame tale of Marguerite's Heptaméron models a diversity of responses and invites its readers, like the devisants, to "answer back, and challenge the message being presented them." 42 Heptaméron 32's suggestion that reading is a kind of conversation in which an ideal reader becomes vulnerable to the beauty of the fiction and then bears responsibility for constructing meaning, and even for taking action in response to that fiction, is among the interpretations that could have registered with sixteenth-century readers or discussants who silently "devised" with written texts, or who told or read this story aloud to friends.

Arizona State University

\section{Notes}

1. Many thanks to Susanne Wofford, Richard Hillman, and the two anonymous readers for Renaissance and Reformation/Renaissance et Réforme, whose generous criticisms and suggestions helped to shape this essay into its current form.

2. For classic contrasting accounts of an exemplary novella frame tale, see, e.g., Guido Almansi, who writes, "Between us readers and the events and characters of the novelle, there is this continuous stylistic artifice which acts as a screen to filter out any direct confrontation between ourselves and the stories which we are supposed to be reading as an artistic construct" (The Writer as Liar: Narrative Technique in the Decameron [London: Routledge, 1975], p. 15), and Lois Potter, who writes that the story-tellers "are meant to be ten representatives of a society in which Boccaccio wholeheartedly believed, ritually secluded during a time of extreme crisis so that they may examine their social universe and learn its values" (Five Frames for the Decameron: Communication and Social Systems in the Cornice [Princeton, NJ: Princeton University Press, 
1982], p. 7). Potter, following Erving Goffman, analyzes the frame as manifesting a shared understanding of "what is going on here" (p. 123).

3. As Cathleen Bauschatz points out, the "anonymous reader ('vous') ... like the narrator Marguerite herself ('je'), makes only a very brief appearance before being replaced by the devisants who alternately sit in for both. That is, the devisants serve as narrators during the tales and as listeners/participants during the discussions. They are able to switch roles easily from authoritative speaker to receptive listener, making the distinction between the two roles much less clear than in most narrative literature" ("Voylà mes dames . . .': Inscribed Women Listeners and Readers in the Heptameron," in Critical Tales: New Studies of the Heptameron and Early Modern Culture, ed. John D. Lyons and Mary B. McKinley [Philadelphia: University of Pennsylvania Press, 1993], p. 105). But see also Deborah Losse, "Authorial and Narrative Voice in the Heptaméron," Renaissance and Reformation/Renaissance et Réforme 23.3 (1987): 223-42, who states that "the prologue of the Heptaméron is not so much a dialogue as a narrative establishing distance between narrator and narratee," yet "the private narrators assume each one a distinctive character, and it is here that we find the female voice" (p. 239).

4. In the terms of the structuralist critic Tsevetan Todorov, novellas invoke a supplement; in other words, each of these brief narratives both calls forth and is nested within another narrative. For Todorov's description of the narrative supplement, see Poetics of Prose, trans. Richard Howard (Ithaca, NY: Cornell University Press, 1977), pp. 66-79 and 108-19.

5. Marguerite de Navarre, L'Heptaméron, ed. Michel François (Paris: Garnier, 1967), p. 9. Subsequent citations of this edition will be included parenthetically in the text.

6. Indeed, in Fiction in the Archives: Pardon Tales and Their Tellers in Sixteenth Century France (Stanford, CA: Stanford University Press, 1987), Natalie Zemon Davis compares Renaissance novellas with pardon tales and argues that in the context of pardon courts, "literary constructions and royal wording" could "influence people who could not read" (p. 112), as humble people attempted to tell the story that would get the pardon.

7. I take the phrase "inscribed listener" from Bauschatz's title, "'Voylà mes dames ...': Inscribed Women Listeners and Readers in Marguerite de Navarre's Heptameron." For a description of this term in relation to reader-response criticism and Wayne Booth's notion of the implied reader, see Susan R. Suleiman's Introduction to The Reader in the Text: Essays on Audience and Interpretation, ed. Susan R. Suleiman and Inge Crosman (Princeton, NJ: Princeton University Press, 1980); cited in Bauschatz, p. 117. The inscribed reader need not constrain the interpretation of the extratextual reader.

8. Within novella collections generally and the Heptaméron in particular, narration and listening are topics of interest. Tales in the Heptaméron ask how desire can be expressed to the beloved $(9,24,57,70)$, what the relation is between speech and desire (19), and how attempted or accomplished rape can be denounced $(4,62)$. They mock eavesdroppers (34) and examine the consequences of unintended revelations $(62,66)$. The overall portrayal of human desire and love as potentially violent and unstable is evident to any reader of the Heptaméron. A particularly brutal example is Oisille's story of the muleteer's wife (2). Parlamente's description of male and female honour, following tale 43, and Hircan's advocacy of rape and murder in pursuit of conquering women, following tale 4, sketch out the boundaries of the collection's treatment of gendered violence.

9. Colette Winn argues that, "Drawing on a code familiar to many cultures, Marguerite associates table encounters with verbal exchanges, which are clearly a major theme of the Heptaméron. In the novel, table encounters almost always precede 'bed' encoun- 
56 / Renaissance and Reformation / Renaissance et Réforme

ters. Thus, table language frequently suggests a more intimate, physical exchange" ("Gastonomy and Sexuality: "Table Language' in the Heptaméron," Journal of the Rocky Mountain Medieval and Renaissance Association 7 [1986]: 17). Implicit in Winn's statement is the notion that speaking, especially in intimate spaces or domestic interiors, can lead to sex. The notion is also evident in numerous romances and novellas and in the prescriptive literature that associated chastity and silence.

10. The woman's chamber can represent her because women are frequently associated with their rooms in novellas, romances and other literature. Georgianna Ziegler traces associations between architectural privacy, enclosure, and women's bodies in Shakespeare and related Renaissance English texts in "My Lady's Chamber: Female Space, Female Chastity in Shakespeare," Textual Practice 4.1 (1990): 77. For examples of violations of a home by visitors perceived as friends (the threat that Bernage could pose), see also Heptaméron 23, in which a Franciscan guest's impersonation of his host in the host's wife's bed results in three deaths, and Heptaméron 8, a double bed-trick, in which a husband unknowingly invites his friend to sleep with his own wife.

11. Colette Winn writes that "In the story of Bernage, the eating ritual, as strange as the mysterious scene of the Graal, reveals a sterile amorous relationship. . . . Her sexual desires are, in fact, repressed by a jealous spouse, determined to render justice. At meals, because she is forced to drink from the skull of her dead lover, horror will forever haunt her desire for food as well as for sex. ... At the table, the lady is chained to the daily repetition of her betrayal, making her incapable of escaping her guilt. The table encounter stands as the crime perpetually denounced, the wound repeatedly reopened" ("Gastronomy," p. 100). I would add that the repetition is as sterile for the husband as for the wife, and that the scene, as his construction, represents his suffering and dysfunction.

12. François's edition of the Heptaméron reports Bernage's words to the lady as "Madame, vostre patience est egalle au torment. Je vous tiens la plus malheureuse femme du monde" (p. 244), a statement that emphasizes her spiritual strength as well as registering her suffering. In Painter's English, Bernage says, "Madame, if your pacience be correspondent to this torment, I deem you to be the happiest woman in the world" (William Painter, The Palace of Pleasure: Elizabethan versions of Italian and French novels from Boccaccio, Bandello, Cinthio, Straparola, Queen Margaret of Navarre, and others, done into English by William Painter, ed. Joseph Jacobs, 4th ed., 3 vols. [1866; rpt. New York: Dover, 1966], 2: 99; subsequent references will be included parenthetically in the text). This variant goes back to sixteenth-century French versions (Bibliothèque Nationale de France, MS. français 1512, MS. fr. 1524, written by Adrien de Thou, and the 1559 printed edition by Claude Gruget) and may simply have been present in the copy that Painter had. Another version, found in the critical edition by Renja Salminen, which takes BN MS. français 2155 as its base text, reads, "Madame, si vostre peché est esgal au tourment, je vous tiens la plus malheureuse femme du monde" (Heptaméron, ed. Salminen [Geneva: Droz, 1999], p. 298). In this last variant, Bernage questions whether the punishment is appropriate to the sin.

13. Félix Lecoy traces related stories of ladies forced to contemplate their lovers' skulls, including tales by Ser Giovanni (the first tale of the second day and the first tale of the seventh day of the Pecorone), Bandello (the twelfth tale of the second book of the Novelle), and Hans Sachs (Historia von dem riter aus Frankreich, den ein kauffman selig nennt), as well as Hue de Rotelande's Protheselaus, in "Un Episode du 'Protheselaus' et le conte du mari trompé," Romania 72 (1955): 477-518.

14. Le Violier des Histoires Rommaines, ed. Geoffroy Hope (Geneva: Droz, 2002), p. 147.

15. Ibid. 
16. A Claude Bernage appears in the service of Louis XI in 1475 and in the service of Charles VIII in 1495 (see François, ed., p. 476, and Salminen, ed., p. 741). The painter Jean Perréal, dit de Paris, served Charles VIII, Louis XII and François I ${ }^{\mathrm{er}}$, and painted Mary Tudor (see François, ed., p. 477, and Salminen, ed., pp. 741-42). On Jean Perréal and the possibility that he painted a Mary Magdalen that has been attributed to Roger van der Weyden, see Jehan Perréal dit Jehan de Paris, peintre et valet de chambre des rois Charles VIII, Louis XII, et François I I ${ }^{\text {er }}$. Recherches sur sa vie et son æuvre (1885; rpt. Geneva: Slatkine, 1970), pp. 28-29; cited in François Rigolot, "Magdalen's Skull: Allegory and Iconography in Heptameron 32," Renaissance Quarterly 47 (1994): 60.

17. Rigolot, pp. 67-68.

18. Ibid., p. 61.

19. Ibid., p. 72.

20. Deborah Losse argues that when the narrator uses dialogue to report directly the husband's account of his killing of the lover and his punishment of his wife's lover, she allows the husband to betray his "caractère vengeur, voire sadique" ("Modes du récit dans la nouvelle française du XVI $\mathrm{X}^{\mathrm{e}}$ siécle," in La Nouvelle: Actes du Colloque International de Montréal [Montréal: Plato Academic Press, 1983], p. 213).

21. Indeed, Losse points out that "on voit l'action tantôt du point de vue du devisant, tantôt de celui de Bernage ou du mari, mais jamais du point de vue de la dame" ("Modes du recit," p. 213). Though Marguerite's adulteress speaks submissive words, she speaks them in constrained conditions. In Protheselaus, a related romance from the twelfth century, a lady who is faced with the bloody severed head of her "ami" at mealtimes smiles each time she sees the head (Lecoy, p. 478).

22. Conduct books of the period testify to concerns about female readers of romance and novellas lacking intellectual and ethical discrimination. E.g., Giovanni Michele Bruto's advice book, published in a trilingual Italian, French, and English edition as The Education of a Young Gentlewoman (1598), proscribes "amorous and impudent verses, or fables and newes, as the tales of Bocace and others" (sig. G4v ). In addition, Boccaccio himself suggests that the Decameron is both a "Galeotto," whose reading can lead to seduction, as it did for Paolo and Francesca as described in Dante's Inferno, and a palliative for the pains of love. Texts that portrayed female readers as flirtatious and passionate, including Barnabe Riche His Farewell to Militarie Profession, George Pettie's Petite Palace of Pettie his Pleasure, and Lyly's Euphues, allowed men to read desirously while gendering this reading female. See Juliet Fleming, "The Ladies' Man and the Age of Elizabeth," in Sexuality and Gender in Early Modern Europe: Institutions, Texts, Images, ed. James Grantham Turner (Cambridge: Cambridge University Press, 1993), pp. 158-81, and Lori Humphrey Newcombe, Reading Popular Romance in Early Modern England (New York: Columbia University Press, 2003).

23. Winn has identified a tension in Marguerite de Navarre's work between the related motifs of "corps prison de l'âme" and "corps [qui] marque l'eveil du Beau" — between a desire to move beyond the body, to renounce the flesh, and a realization that one experiences in and through the body the beauty and suffering which leads the soul to God (Colette Winn, “Trop en Corps: Figures du corps transgressif dans l'œuvre de Marguerite de Navarre," in International Colloquium Celebrating the 500th Anniversary of the Birth of Marguerite de Navarre, ed. Régine Reynolds-Cornell [Birmingham, AL: Summa, 1995], p. 94).

24. Of the stories told by Oisille, the "mother" of the storytellers (identified by scholars as Marguerite de Navarre's mother, Louise de Savoie) and a voice of religious and ethical authority in the Heptaméron, stories 2, 23, and 51 involve rape or the killing or 
58 / Renaissance and Reformation / Renaissance et Réforme

torture of a woman by her husband (or, in story 51 , by the Duke). In addition, story 70 ends in the death of two lovers, when a jealous rival publicizes their love.

25. As François Cornilliat's and Ullrich Langer's discussion of Heptaméron 62 shows, Parlamente maintains the position that "women must resist the permanent provocation that the storytelling activity itself constitutes, as a machine for exposing feminine desire in order to excuse/deflect men's violence through laughter" (François Cornilliat and Ullrich Langer, "Naked Narrator: Heptameron 62," in Critical Tales: New Studies of the Heptameron and Early Modern Culture, ed. John D. Lyons and Mary B. McKinley [Philadelphia: University of Pennsylvania Press, 1993], p. 133).

26. Bauschatz, p. 107.

27. Ibid., p. 110.

28. On the unmarked pages of Renaissance women's books, see Heidi Brayman Hackel, "The Countess of Bridgewater's London Library," in Books and Readers in Early Modern England: Material Studies, ed. Jennifer Andersen and Elizabeth Sauer (Philadelphia: University of Pennsylvania Press, 2002), p. 146.

29. On the mutual influence of orality and literature in the period, see Adam Fox, Oral and Literate Culture in England, 1500-1700, Oxford Studies in Social History (Oxford: Oxford University Press, 2002). On the pervasiveness and significance of manuscript circulation, see Arthur Marotti, Manuscript, Print, and the English Renaissance Lyric (Ithaca, NY: Cornell University Press, 1995), and Margaret J. M. Ezell, Social Authorship and the Advent of Print (Baltimore, MD: Johns Hopkins University Press, 1999).

30. For a thorough enumeration of the functions of the preface, and other paratextual material, see Gerard Genette, Seuils (Paris: Seuil, 1987), translated by Jane E. Lewin as Paratexts: Thresholds of Interpretation (Cambridge: Cambridge University Press, 1987).

31. Wendy Wall, Imprint of Gender: Authorship and Publication in the English Renaissance (Ithaca, NY: Cornell University Press, 1993).

32. The representation of women as active interpreters, analyzing and telling stories in the context of discussions about social norms, contrasts with the demands of conduct books for women to read for static models of virtue, as traced by Eve Sanders in Gender and Literacy on Stage in Early Modern England (Cambridge: Cambridge University Press, 1998), esp. p. 66. Indeed, although it could be argued that the frequent novella topics of love and illicit sex could block participation by real historical women who needed to protect a reputation for chastity (see, e.g., Mary Ellen Lamb's introduction to her book, Gender and Authorship in the Sidney Circle [Madison: University of Wisconsin Press, 1990]), in fact, a number of women wrote novellas or presided over gatherings in which they were read. For more on women writing novellas, see Janet Smarr, "Boccaccio and Renaissance Women," Studi sul Boccaccio 20 (1991-92): 279-97.

33. Though writers did not necessarily receive patronage as a result of such dedications, it appears that Painter's dedication to Ambrose Dudley reflected or enhanced a relationship that did benefit Painter. The Warwick emblem of the bear and the ragged staff appears on the title page of the Palace, and Dudley and Painter collaborated in embezzling money from the office of the Ordnance, to the point where Painter, with an official salary of eight pence a day, was able to buy several manors (DNB). On writers' use of textuality to establish patronage links, see Lorna Hutson, The Usurer's Daughter (London: Routledge, 1994), especially Chapter Two.

34. Wall, p. 12 
35. In doing so, he likely provides an occasion for the anxiety about softening class distinctions discussed by Wall.

36. Painter did add moralizing commentary to several stories he translated from the Decameron, including Decameron 2.2: "To be shorte, this lecherous lady, burning inwardlye with amourous desyre, abused her selfe with hym, in steed of the Marques [the lover who had failed to keep his appointment]" (1: 129). Herbert G. Wright gives a summary of these additions (Boccaccio in England from Chaucer to Tennyson [London: Athlone Press, 1957], p. 159). Painter also declined to translate some of Boccaccio's tales because "there be some . . . that be worthy to be condemned to perpetual prison" (1: 11) in the Italian tongue.

37. On the Renaissance recommendation that women read in order to emulate static models of virtue or be relegated to equally restrictive portraits of vice, see Sanders, esp. pp. 66-68. Sanders argues that in Hamlet, when Ophelia reads on stage, she appears to Polonius and Hamlet as "Devotion ... an icon, not an agent" (p. 57), and that "falling short of the ideal turns her into the anti-ideal" (p. 68). Heptaméron 32 investigates the construction of another iconographic female figure, a figure of humble penitence, when the only possible female interpreter within the tale itself splits into the fertile woman of the tale's conclusion and the portrait painted by the king's painter. But Heptaméron 32 juxtaposes this non-speaking woman with the devisants of the frame tale, who are reflective and articulate interpreters.

38. He need not have bothered, as in 1570 , shortly after the first volume of the Palace came out, Roger Ascham denounced such tales, arguing that "ten Morte Arthures do not the tenth part of so much harme, as one of these bookes made in Italie, and translated in England. They open, not fond and common wayes to vice, but such sutle, cunnyng, new, and diuerse shiftes, to cary yong willes to vanitie, and young wittes to mischief, to teach old bawds new schole poyntes, as the simple head of an English man is not hable to inuent" (The Scholemaster [London: John Daye, 1570], fol. 27v). Moreover, "These be the inchantements of Circe, brought out of Italian into English and sold in every shop in London, commended by honest titles the sooner to corrupt honest manners: dedicated over boldlie to vertuous and honorable personages, the easier to beguile simple and innocent wits" (fol. $26^{\mathrm{V}}$ ). In other words, Ascham saw such tales as a sort of literary equivalent of the Trojan horse.

39. George Whetstone, An heptameron of ciuill discourses (London : Richard Iones, 1582), sig. $* \mathrm{ii}^{\mathrm{V}}-* \mathrm{iii}^{\mathrm{v}}$; subsequent citations will be documented parenthetically in the text. Whetstone's Heptameron was reprinted under the title of Aurelia: The paragon of pleasure and princely delights in 1593. The Heptameron of Civil Discourses is also available in the thorough Critical Edition of George Whetstone's Heptameron of Civill Discourses, ed. Diana Shklanka, The Renaissance Imagination 35 (New York: Garland Publishing, 1987).

40. Whetstone was also influenced by Castiglione's The Book of the Courtier and Guazzo's Civil Conversation. See Shklanka, ed., Critical Introduction, for the background of courtesy literature from which Whetstone drew.

41. See Shklanka, ed., Critical Introduction, esp. pp. 1xvi-lxxi, for a cogent discussion of the place of the Heptameron of Civill Discourses in the corpus of Renaissance marriage literature. As Shklanka points out, marriage literature often contrasted more idealized Petrarchan portrayals of love. While the novellas in the collection "reveal how courtly ideals do not work in real life" (p. lxxi), Whetstone's volume also includes Petrarchan love poems.

42. Bauschatz, p. 116. 